\title{
Coffee husk mulch on soil erosion and runoff: experiences under rainfall simulation experiment
}

\author{
H. Moreno-Ramón ${ }^{1}$, S. J. Quizembe ${ }^{2}$, and S. Ibáñez-Asensio ${ }^{1}$ \\ ${ }^{1}$ Department of Plant Production, Universitat Politècnica de València, Valencia, Spain \\ ${ }^{2}$ Instituto de Investigações Agrárias de Angola (IIA), Chiamba, Huambo, Angola \\ Correspondence to: S. Ibáñez-Asensio (sibanez@prv.upv.es)
}

Received: 28 March 2014 - Published in Solid Earth Discuss.: 6 May 2014

Revised: 9 July 2014 - Accepted: 11 July 2014 - Published: 26 August 2014

\begin{abstract}
The high erosion rates found in the agriculture land make valuable the use of mulches to control the soil and water losses. Coffee husk (Coffea canephora var. robusta) can be one of those mulches. This paper evaluates how to apply the mulch in order to obtain the best effectiveness. An experimental factorial design $4 \times 3 \times 2$ with two replicates was designed in a greenhouse with a total number of 48 cases. All the samples were deposited in trays of $0.51 \mathrm{~m}^{2}$ and applied a simulated rain of $122 \mathrm{~mm} \mathrm{~h}^{-1}$ during $21 \mathrm{~min}$. The factors examined were the following: four soil classes; three treatments - buried (B), surface (S) and non-residue (C) - and the presence (WC) or absence (WOC) of the soil surface crusting. The coffee husk residue ( $\mathrm{S}$ and B treatments) reduced runoff by 10.2 and $46 \%$ respectively, soil losses by 78.3 and $88.7 \%$ and sediment concentration by 77 and $84.4 \%$. The infiltration rate increased on average by 104 and $167 \%$, and time to runoff by 1.58 and 2.07 min respectively. Coffee husk is an efficient mulch to reduce the soil and water losses, although it could not completely cushion the influence of crust.
\end{abstract}

\section{Introduction}

It is estimated that 20 million $\mathrm{km}^{2}$ of agricultural lands are affected by soil erosion in the world, and 1.3 million $\mathrm{km}^{2}$ are affected by water soil erosion in Europe (Montgomery, 2012; Hockbridge, 2012). The developing countries have very high erosion rates due to the deforestation, the agricultural expansion and the use of fire for the shifting agriculture (Zhao et al., 2013). Soil losses by water erosion occur due to the detachment and transport of soil particles during the rainfall and runoff processes (Ellison, 1944; Laws, 1940; Fernández et al., 2012; Ziadat and Taimeh, 2013). Soil cover reduces the amount of runoff generated, decreases runoff velocity and increases infiltration because it protects the soil surface against kinetic energy of drops (Bielders et al., 1996; Cerdà, 2001; Grismer and Hogan, 2004; Groen and Wood, 2008).

The research about mulch application reveals that its efficiency depends on both the residue quality and its management (Gangwar et al., 2006). If the residue is applied to the surface as mulch, the improvement of the soil physical properties and the increase of soil organic carbon (SOC) occur over time. In contrast when the residue is buried, there is a fast improvement of soil quality, but at the beginning its capacity to protect the soil surface seems less efficient. It is also clear that the best way to apply it to the soil and the precise incorporation rate are the keys to success (El Kateb et al., 2013; Ma and Li, 2011; Mashingaidze et al., 2012; Singh et al., 1994; Lee et al., 2013; Jiménez et al., 2013).

It is important to know the advantages or inconveniences associated with each management practices before proceeding with the mulch application. Bakr et al. (2012) found that, in relation to soil losses, the effectiveness is lower in tilled soils than in soils with superficial application, whereas Abdelkadir and Yimer (2011) revealed the suitability of breaking the compacted superficial layer to increase the infiltration rate in loamy soils. There is a close relationship between erosion and the protective layer of mulch, but there are several authors like Jin et al. (2008), Ma and Li (2011) and Thierfelder and Wall (2009) who indicated that the degree of effectiveness depends largely on soil permeability, percentage of soil surface cover, SOC, and also the interactions among the variables. Findeling et al. (2003) and Le Bissonnais et al. (2005) highlighted that the soil behavior under the rainfall 
thunderstorms is strongly influenced by compaction and surface crusting, and it is regardless of the specific quality of soil. Bielders et al. (1996) concluded that mulch can be the main cause that affects the thickness and crust type in soils, and Vandervaere et al. (1998) demonstrated that top layer characteristics are the key factor for controlling the infiltration process in crusted soils.

The use of simulated rainfall technique is common in erosion soil studies, and several rainfall simulations have been applied on different mulches and soil conditions. In that kind of research, the aim is to determine the influence of one individual factor on the soil characteristics (Cerdà, 1998; Brodie and Misra, 2009; Calvo-Cases et al., 2003; Huang et al., 2012).

Different mulches have been tested to protect soil - rice straw, wood and olive residues, pine needle, and other vegetable residues (Cerdà and Doerr, 2008; García-Orenes et al., 2012; Prats et al., 2012; Jiménez et al., 2013) - and to improve the soil quality (Stavi et al., 2012). However, the review of the scientific literature published about mulch in soil conservation shows us that the use of coffee husks as mulch has not been investigated yet. After a complete review, Gholami et al. (2012) reflected in their research the necessity of further studies about mulches and experimentally different conditions. The coffee husk is a residue generated in the coffee production process and constitutes around $50 \%$ of dry residue in coffee fruit business. It is usually removed by combustion with the following consequent environmental problems: heat, $\mathrm{CO}_{2}$ emissions and fly ash (Saenger et al., 2001). Its development as industrial use - bioethanol, aroma production, wood particle board manufacture, clay and food industry or livestock feed (Prata and Oliveira, 2007; Choi et al., 2012; Bekalo and Reinhart, 2010; Murthy and Naidu, 2012) - has been higher than the gardening and agriculture uses: compost or substrate (Kasongo et al., 2011; Santos et al., 2001). However, these uses do not solve the problem of the coffee husk waste.

In that regard, although the researchers have begun to explore the possibilities of recycling coffee husk in the last decade, there is not any research that has thought to use it as a soil protector. The hypothesis of this paper is that coffee husk could be used as mulch to reduce soil erosion. In that sense, this agricultural resource could be a solution for soil erosion problems in coffee-producing countries, and, at the same time, it could reduce the environmental problems of its combustion. The main objectives are the following: (i) to determine the capacity of coffee husk to reduce the erosion, (ii) determine which is the best location to apply the mulch with the same surface cover percentage, (iii) assess whether the mulch is able to cushion the effect of soil crust, and (iv) determine whether the soil characteristics can affect the behavior of the mulch in response to soil erosion parameters. To control hydrological and erosive soil variables, a laboratory rainfall simulation experiment on soil erosion trays was developed.

\section{Materials and methods}

\subsection{Experimental design}

An experimental factorial design with three independent variables was designed. The factors were (i) soil class (I, II, III and IV), (ii) treatment - bare soil or control (C), superficial deposition of coffee husk (S), buried coffee husk (B); and (iii) soil crusting - presence (WC) or absence of surface crust (WOC). The combination of these factors resulted in 24 experimental cases, which were replicated twice. The total number of simulated rainfall experiments was 48 (4 soils types $\times 3$ treatments $\times 2$ crust conditions $\times 2$ replicates). The measured dependent variables were time to runoff $(\mathrm{min})$, runoff $(\mathrm{mm})$, infiltration rate $\left(\mathrm{mm} \mathrm{h}^{-1}\right)$, soil loss $\left(\mathrm{g} \mathrm{m}^{-2}\right)$ and sediment concentration $\left(\mathrm{g} \mathrm{L}^{-1}\right)$.

\subsection{Erosion trays and soil preparation}

The rainfall simulations were carried out on air-dried soil samples collected in the Turia River alluvial plain (Valencia, Spain). The soils were sampled in agriculture fields with conventional tillage, and they were formed over quaternary materials, rich in carbonates, slightly stony and with loam texture. Despite the fact that the soils were fairly homogeneous, they showed differences in the content of organic matter and salts (Table 1). The upper $20 \mathrm{~cm}$ of the profile were taken and mixed in a big container in the greenhouse. After this step, they were deposited in galvanized aluminum trays $(74.9 \mathrm{~cm}$ length $\times 67.9 \mathrm{~cm}$ width $\times 10 \mathrm{~cm}$ height $)$.

The soil analyzed parameters were carbonate content $\left(\mathrm{CaCO}_{3}\right)$ by Bernard calcimeter method, electrical conductivity of saturated extract $\left(\mathrm{EC}_{\mathrm{e}}\right), \mathrm{pH}$, organic matter $(\mathrm{OM})$ by Walkley-Black method, field capacity (FC) and wilting point (WP) by pressure plate method, texture by Bouyoucos method and sodium absorption ratio (SAR) by main cations and anions. Hydraulic conductivity was obtained by a constant charge permeameter method, whereas porosity was obtained by mercury porosimeter and aggregate stability by wet sieving. The soil samples were analyzed according to the Soil Survey Staff (2014), and they were collected in disturbed samples for textural and chemical analysis and in core samples for physical and hydrological properties.

The coffee husk is a by-product from the coffee bean dry processing, and it is composed of carbohydrates, pectins, proteins, tannins, fat and caffeine (Pandey et al., 2000). The husk used in this experiment was from the Angolan coffee region with maximum storage capacity of $6.9 \%$ of moisture. The organic content was $2.5 \%$, bulk density values between 0.32 and $0.35 \mathrm{~g} \mathrm{~cm}^{-3}$, and the diameter of husk between 0.5 and $1.5 \mathrm{~cm}$.

According to previous studies (Prats et al., 2012; Montenegro et al., 2013), the soil coverage percentage was $80-85 \%$ in the $\mathrm{S}$ and $\mathrm{B}$ trays. To obtain the same cover, an amount of $0.73 \mathrm{~kg} \mathrm{~m}^{-2}$ of coffee residue on the $\mathrm{S}$ trays and a $1.6 \mathrm{~kg} \mathrm{~m}^{-2}$ 
Table 1. Analytical characteristics of soils.

\begin{tabular}{lllll}
\hline Soil parameters & I & II & III & IV \\
\hline $\mathrm{pH}$ & 8.5 & 8.44 & 8.08 & 8.53 \\
$\mathrm{CE}_{\mathrm{e}}\left(\mathrm{dS} \mathrm{m}{ }^{-1}\right)$ & 3.95 & 5.49 & 7.89 & 5.51 \\
$\mathrm{CaCO}_{3}(\%)$ & 34 & 30.8 & 24.9 & 34.1 \\
$\mathrm{RAS}$ & 1.71 & 3.35 & 4.64 & 4.46 \\
Organic matter (\%) & 6.27 & 1.6 & 2.51 & 1.57 \\
Field capacity (\%) & 8.83 & 9.42 & 9.16 & 6.88 \\
Wilting point (\%) & 4.04 & 5.13 & 5.49 & 3.57 \\
Clay (\%) & 27 & 29 & 27 & 24 \\
Silt (\%) & 42 & 22 & 14 & 22 \\
Sand (\%) & 31 & 49 & 59 & 54 \\
Textural class (USDA) & Clay loam & Sandy clay loam & Sandy clay loam & Sandy clay loam \\
Hydraulic conductivity $\left(\mathrm{cm} \mathrm{h}^{-1}\right)$ & 1.85 & 1.43 & 1.75 & 2.14 \\
Porosity (\%) & 40.5 & 41.5 & 51.5 & 42 \\
Aggregate stability (\%) & 2.3 & 2.4 & 1.9 & 2.7 \\
\hline
\end{tabular}

on B trays ( $0.05 \mathrm{~m}$ of depth) were incorporated and mixed respectively before the crust formation. The same cover surface percentage was chosen with the aim of avoiding an interference in the erosion results due to the different amount of residue on the soil surface. Findeling et al. (2013) concluded that, in the same experimental conditions, a small amount of residue applied on the soil surface could dramatically cut down the runoff. In this regard, the application of the same dose in both treatments ( $\mathrm{S}$ and B) would have caused a clear difference in the amount of residue on the surface. In concordance with Leys et al. (2010), about 2 or 3 times more material in buried treatments is necessary to achieve the same percentage of soil cover. This larger dose of coffee husk in the buried treatment increased the amount of soil organic matter although the organic matter content in the coffee husk was low $(2.5 \%)$. It showed a higher content of inorganic compounds compared to organic compounds. To sum up the priority was to obtain the same soil surface protection against the erosion forces, and the unique way was to maintain the same surface cover.

Once the trays were prepared, one of each treatment pair was periodically dampened for a period of 6 months to generate surface crusts (Fig. 1). At least five cycles of wettingdrying were applied monthly. Distilled water was sprayed on the soil surface to avoid the runoff generation. When the damping cycles were finished, soil trays were left at ambient temperature until they were completely dry.

The trays were placed at $12 \%$ of slope under the rainfall simulator, and they were prepared without stones or vegetation that protect soil from the direct impact of rainfall drops. Slope and vegetation conditions (12 and $0 \%$ respectively) reproduced the unfavorable soil condition, which is common in some coffee agricultural areas. The laboratory layout was provided with a collector system at the end of the tray, which collected the runoff (Fig. 1).
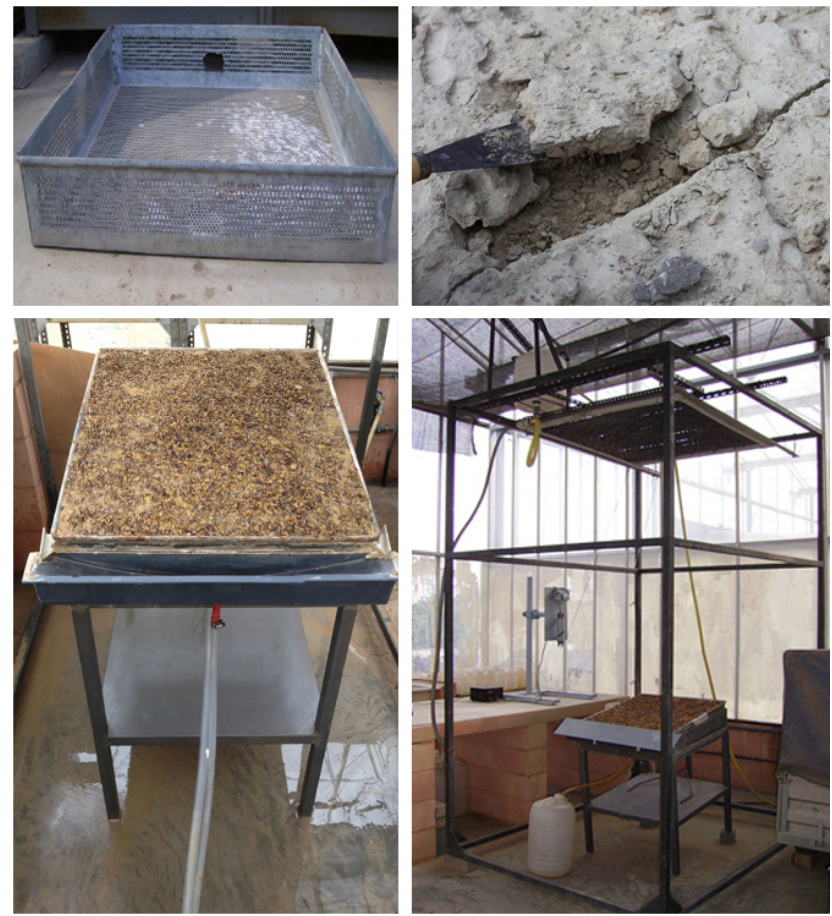

Figure 1. Experimental equipment and crust formation.

\subsection{Simulated rainfall}

The rainfall simulator was a metallic structure of $3.08 \mathrm{~m}$ of height and $1.99 \mathrm{~m}$ wide by $1.59 \mathrm{~m}$ length (Fig. 1). A water tank with a capacity of $25 \mathrm{~L}$ and a device with 51 rows and 255 droppers were placed at the top of the metallic structure. The distance between the erosion tray and the droppers was $2 \mathrm{~m}$. The water level inside the tank was constant, so the hydrostatic pressure did not suffer any change and the droppers supplied the same amount of rainfall along the simulation. 
Table 2. Influence of factor levels over the studied parameters (average values).

\begin{tabular}{lllllll}
\hline Factors & Levels & $\begin{array}{l}\text { Time to runoff } \\
(\mathrm{min})\end{array}$ & $\begin{array}{l}\text { Runoff } \\
(\mathrm{mm})\end{array}$ & $\begin{array}{l}\text { Infiltration rate } \\
\left(\mathrm{mm} \mathrm{h}^{-1}\right)\end{array}$ & $\begin{array}{l}\text { Soil loss } \\
\left(\mathrm{g} \mathrm{m}^{-2}\right)\end{array}$ & $\begin{array}{l}\text { Sediment concentration } \\
\left(\mathrm{g} \mathrm{L}^{-1}\right)\end{array}$ \\
\hline \multirow{2}{*}{ Treatment } & Superficial & $2.20 \mathrm{~b}^{*}$ & $20.87 \mathrm{a}$ & $47.98 \mathrm{a}$ & $235.04 \mathrm{a}$ & $11.47 \mathrm{a}$ \\
& Buried & $2.69 \mathrm{~b}$ & $12.48 \mathrm{~b}$ & $77.09 \mathrm{~b}$ & $121.92 \mathrm{~b}$ & $10.63 \mathrm{a}$ \\
& Control & $0.62 \mathrm{a}$ & $23.24 \mathrm{a}$ & $46.10 \mathrm{a}$ & $1084.07 \mathrm{c}$ & $46.19 \mathrm{~b}$ \\
\multirow{5}{*}{ Soil condition } & Without crust & $2.25 \mathrm{a}$ & $15.57 \mathrm{a}$ & $65.94 \mathrm{a}$ & $389.50 \mathrm{a}$ & $22.43 \mathrm{a}$ \\
& With crust & $1.42 \mathrm{~b}$ & $22.16 \mathrm{~b}$ & $48.19 \mathrm{~b}$ & $571.18 \mathrm{a}$ & $23.09 \mathrm{a}$ \\
& I & $1.99 \mathrm{a}$ & $18.19 \mathrm{a}$ & $55.89 \mathrm{a}$ & $644.07 \mathrm{a}$ & $30.66 \mathrm{a}$ \\
\multirow{5}{*}{ Soil class } & II & $1.92 \mathrm{a}$ & $20.62 \mathrm{a}$ & $52.89 \mathrm{a}$ & $431.61 \mathrm{a}$ & $19.66 \mathrm{a}$ \\
& III & $1.5 \mathrm{a}$ & $16.52 \mathrm{a}$ & $65.52 \mathrm{a}$ & $334.26 \mathrm{a}$ & $16.26 \mathrm{a}$ \\
& IV & $1.97 \mathrm{a}$ & $20.14 \mathrm{a}$ & $53.94 \mathrm{a}$ & $511.44 \mathrm{a}$ & $24.48 \mathrm{a}$ \\
\hline
\end{tabular}

* Values with different letter $(\mathrm{a}, \mathrm{b}, \mathrm{c})$ in each column are significantly different $(p \leq 0.05)$.

The average droplet diameter was $5.76 \mathrm{~mm}$, and the falling drop speed between 4.7 and $5.5 \mathrm{~m} \mathrm{~s}^{-1}$. Each erosion tray was subjected to a total rainfall of $21 \mathrm{~min}$ and an intensity of $122 \mathrm{~mm} \mathrm{~h}^{-1}$ with non-saline water $\left(\mathrm{CE}<2 \mathrm{dS} \mathrm{m}^{-1}\right)$. The kinetic energy generated was $12.6 \mathrm{Jl} \mathrm{m}^{-2} \mathrm{~mm}^{-1}$ and the Christiansen uniformity coefficient of $98 \%$. To obtain uniformity in the rainfall, we attached a mechanical stirrer to the device. Ibáñez (2001) measured the rainfall characteristics of the simulated rainfall.

\subsection{Data collection and calculated variables}

The runoff was picked up in plastic containers at intervals of $3 \mathrm{~min}$. Seven volumes were taken during the $21 \mathrm{~min}$ for each rainfall simulation. Subsequently, the runoff was filtered in a calibrated paper that had been previously gauged, and the solid losses were determined by the gravimetric method. The total runoff $(\mathrm{mm})$ was calculated by adding the seven volumes generated. Data, water volumes and sediment weight were used to calculate soil losses $\left(\mathrm{g} \mathrm{m}^{-2}\right)$ and sediment concentration $\left(\mathrm{g} \mathrm{L}^{-1}\right)$.

The Horton (1940) equation was used to estimate the infiltration rate $\left(\mathrm{mm} \mathrm{h}^{-1}\right)$, and the steady-state infiltration rate after $1 \mathrm{~h}\left(\mathrm{~K}_{1 \mathrm{~h}}\right)$ was calculated. This parameter is the infiltration rate when the soil is completely saturated under a constant rainfall intensity. In the experimental conditions, at $1 \mathrm{~h}$, all the erosion trays reached this situation. Previous studies have demonstrated the efficiency of Horton's regression for the determination of the infiltration rate at saturation conditions (Ibáñez, 2001; Telis, 2001; Hsu et al., 2002).

\subsection{Statistical analyses}

The data were statistically analyzed by non-parametric methods because the set of data did not show a normal behavior with the Shapiro-Wilk test. The Mann-Whitney and Kruskal-Wallis tests were applied to the data with the aim of finding the relationships among the factors (categorical independent variables) and determined parameters (quantitative dependent variables). The statistically significant differences were tested at 0.05 and 0.01 level. The analyses were completed using the computer software package SPSS and Statgraphics Centurion XVI.I.

\section{Results and discussion}

\subsection{Soil characteristics}

The analytical results of soil initial conditions are shown in Table 1, where the main characteristics are reflected. Soil III was the most saline $\left(\mathrm{EC}_{\mathrm{e}}=7.89 \mathrm{dS} \mathrm{m}^{-1}\right)$ whereas soil I had the highest content of organic matter $(\mathrm{OM}=6.27 \%)$. Soil II had the largest water storage capacity, in contrast with soil IV that showed the lowest $(9.42-6.88 \%$ respectively).

\subsection{Runoff}

The average data of time to runoff (minutes) and runoff depth $(\mathrm{mm})$ for the different factors (treatment, soil condition and soil class) are shown in Table 2. Figure 2a shows the absence of crust on the runoff values for the combinations between soil class and treatments. Equally, the influence of crust is shown in Fig. 2b.

In reference to onset of runoff, $\mathrm{S}$ and B treatments delayed its generation by 3.5 and 4.3 times compared to control (Table 2). C treatments showed significant differences from coffee husk incorporation (S or B) $(p<0.01)$. Also, the soil crusting had a significant influence over the time to runoff. The absence of soil crust increased the time to runoff by 1.58 times. Average time to runoff in descending order was B-WOC $\left(3.37^{\prime}\right)>$ S-WOC $\left(2.74^{\prime}\right)>$ B-WC $\left(2.02^{\prime}\right)>$ SWC $\left(1.67^{\prime}\right)>$ C-WOC $\left(0.65^{\prime}\right)>$ C-WC $\left(0.59^{\prime}\right)$. Therefore, the most favorable situation was buried without crust surface and the control treatments were the worst. Soil class did not show statistically significant difference over time to runoff, although the soil III showed less time in runoff generation.

The incorporation of the coffee husk on the soil surface was able to absorb the kinetic energy of rainfall and maintain 


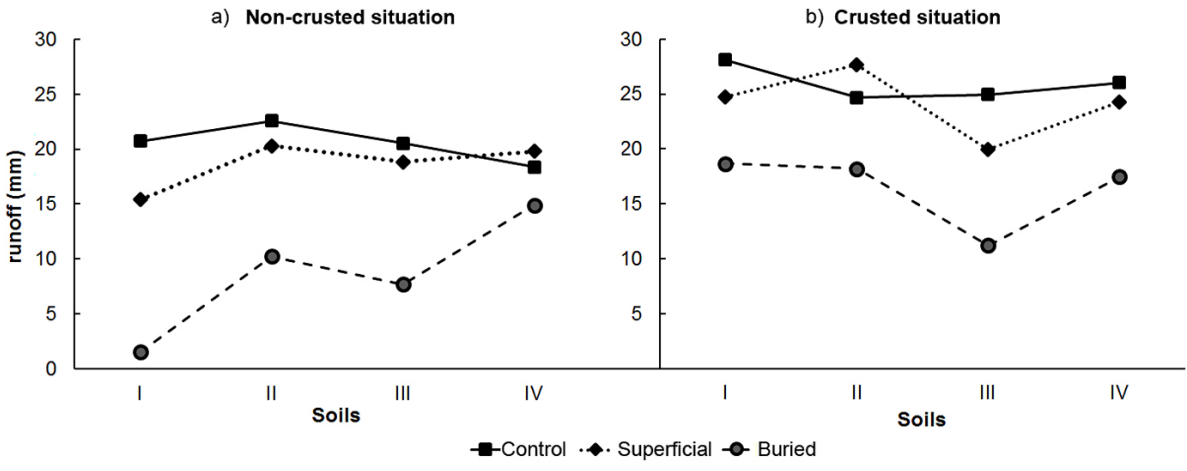

c) Non-crusted situation

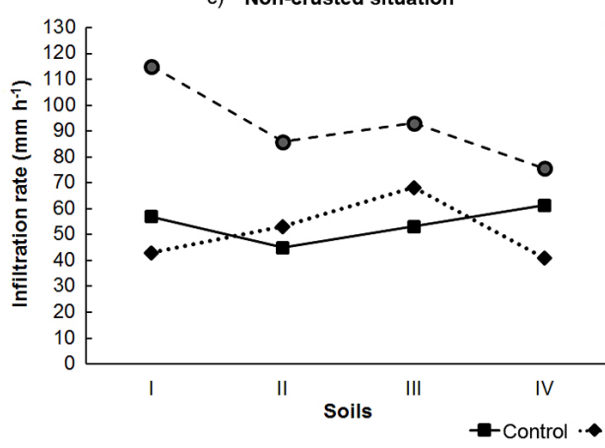

d) Crusted situation

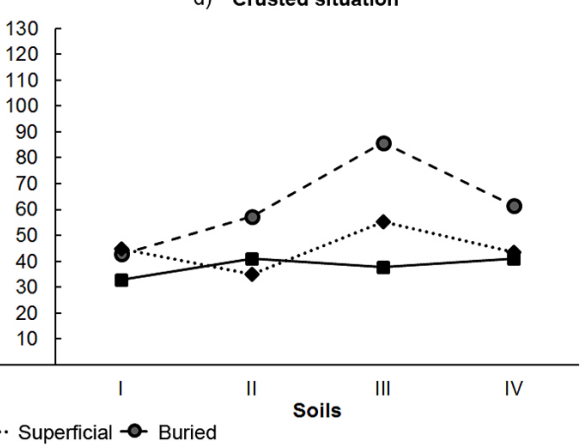

Figure 2. Behavior of hydrological variables in function of the studied factors: runoff (a) without crust, (b) with crust, and infiltration rate (c) without crust, (d) with crust.

soil aggregates longer. In consequence, the runoff took more time to reach the collecting container. In addition, there was an increase in the tortuosity of water pathways due to the higher roughness, and some amount of water was used to soak the coffee husk. The same situations have been reported by others authors (Findeling et al., 2003; Montenegro et al., 2013). This behavior caused the time to runoff in S and B to be longer than $\mathrm{C}$, but it could not explain why B treatments showed higher values than $\mathrm{S}$. Both treatments had the same surface coverage percentage (80-85\%), and therefore the same protection against the rainfall, roughness and absorption or retention ability of surface water. As the results of Jin et al. (2008) and Stavi et al. (2012), the main reason for this difference was that the buried treatment had achieved in improving the physical and chemical properties of soil. These improvements were higher in B than in S, and facilitated the water movement in soil because mulches had improved the soil quality.

In Table 3, you can see the average values of aggregate stability and porosity measured after the rainfall simulations in each erosion tray. If the initial data (Table 1) are compared with the porosity results in $\mathrm{S}$ treatments after the simulation, there was an increase between 1.3 and $16.9 \%$, whereas B treatments showed an upsurge between 13.5 and $24.6 \%$. In relation to aggregate stability, $\mathrm{S}$ treatments registered a rise of 2.3-3.4 times more than C, while B treatments showed
Table 3. Soil physical properties after the experiment.

\begin{tabular}{llll}
\hline Soil Class & Treatment & Porosity $(\%)$ & $\begin{array}{l}\text { Aggregate } \\
\text { stability }(\%)\end{array}$ \\
\hline I & Superficial & 51.75 & 5.73 \\
& Buried & 60.00 & 25.20 \\
II & Superficial & 48.50 & 5.73 \\
& Buried & 51.70 & 12.91 \\
III & Superficial & 46.00 & 6.43 \\
& Buried & 50.00 & 19.18 \\
IV & Superficial & 45.00 & 9.44 \\
& Buried & 47.65 & 14.88 \\
\hline
\end{tabular}

an increase between 5.4 and 10.9 times. Kukal and Sarjkar (2010) showed a variation of soil aggregates values in semiarid areas due to the application of plant residues as mulch. The improvement was related to the mulch application rate.

Physical-chemical properties conditioned the runoff amount generated by rainfall. High values of aggregate stability and porosity promoted lower runoff depth. The drop impacts break the aggregates which present low stability during rainfall, and the porous space begins to be filled. In this situation, if the aggregation stability is improved, the porosity remains more stable over time due to the resistance of aggregates to destruction (Nearing and Bradford, 1985). The 
results showed that the aggregates were stronger, and the soils generated less runoff with the same amount of rainfall. As you can see in Table 2, buried treatments revealed a reduction of $40.2 \%$ in runoff depth with respect to superficial treatments, and $\mathrm{S}$ treatments showed only a $10.2 \%$ reduction compared to $\mathrm{C}$ treatments. Runoff values were smaller in buried treatments for both soil conditions (Fig. 2c and d). The $\mathrm{C}$ and $\mathrm{S}$ treatments did not show statistically significant differences between themselves in runoff depth values, so this outcome revealed the lower efficiency of spreading the coffee husk on the surface. The treatment factor was statistically significant $(p<0.01)$ due to the influence of B treatments, which showed differences with $\mathrm{C}$ and $\mathrm{S}$ (Table 2). In any case, the best reduction was between $\mathrm{B}$ and $\mathrm{C}$ treatments $(46 \%)$.

Regarding the effect of the crust and runoff amount, the enhancements in the properties were quite good after the coffee husk application. B-WC trays showed a lower value than S-WOC and C-WOC - specifically, B-WC $(16.31 \mathrm{~mm})$ $<$ S-WOC $(18.51 \mathrm{~mm})$ and C-WOC $(20.54 \mathrm{~mm})$. Therefore, it would be highly recommended burying the residue in soils with a tendency to form crusts.

In general, crusting conditions modify quickly the hydraulic properties and limit soil infiltration (Bielders et al., 1996). Le-Bissonnais and Singer (1992) found that the runoff rate for soils with crust reached values around $25 \mathrm{~mm} \mathrm{~h}^{-1}$, whereas non-crusted soils did not register runoff. As you can see in Fig. 2a and b, the crusted situations recorded higher values than non-crusted cases for any soil class. There was a difference of $6.59 \mathrm{~mm}$ on average (Table 2) between the two studied situations (absence or presence of crust). We must pay attention in the future to the crust water repellency, because it can be one reason for this behavior, and it has been found in other soils of the region (Bodí et al., 2013). In that regard, the statistically significant difference $(p<0.01)$ was revealed in soil crusting factor but not in soil class factor. Soils I, II and IV registered runoff average values between 18 and $20 \mathrm{~mm}$ (including any treatments and all surface situations), whereas soil III showed the lowest value $(16.52 \mathrm{~mm})$, despite the fact that it was the first to generate runoff (Tables 2 and 4 ).

In crusted soils the action of burying the coffee husk did not maintain the runoff depth at the same levels as the noncrusted (Fig. 2a and b). In soils III and IV between B-WOC and B-WC, there was a variation of $3 \mathrm{~mm}$, in soil II the difference was $8 \mathrm{~mm}$ and in soil $\mathrm{I} 17 \mathrm{~mm}$. Therefore, the action of spreading the mulch on soil surface did not avoid the crust effect over runoff generation.

The time to runoff results were similar to other studies where the mulch application registered a decrease in the onset of runoff. On the one hand, Gholami et al (2012) developed a similar laboratory experiment in erosion trays and rainfall simulation. The surface coverage and slope were 90 and $30 \%$, respectively. They used rice straw as mulch and registered a reduction by 1.44 and 2.42 times after the appli- cation. Raindrop protection by mulch and the delay of water progress due to the surface resistance were the main causes of their results, and they were in concordance with the outcomes registered with coffee husk. The results of Montenegro et al. (2013) were the same way, because they registered a reduction between 4.07 and 6.63 times in time to runoff. They used rice straw, and the differences between those outcomes were related to the surface coverage: 63.1 and $80.3 \%$. Therefore the coverage surface was an important factor in erosion studies, and its value had a great influence in the onset of runoff. Thierfelder et al. (2013) developed their studies on two farm sites, where the crop residues from previous years (maize) were used as surface mulch. They measured the time taken for the water to flow out of a metal ring, and with mulch application the time to runoff was increased between 1.13 and 1.21 times. In the same rank of results, Groen and Woods (2008) and Grismer and Hogan (2004) registered a delay of time to runoff in forest areas after the mulch application. In the literature review, there was always a delay in time to runoff when the mulch was applied. In general, the outcomes were dependent on the slope, the soil features and the mulch characteristics, although in all the cases, there was a delay that was beneficial for soil after the mulch application.

On the other hand, in relation to runoff generation, Thierfelder and Wall (2009) compared conventional tillage with conservation techniques and found a reduction between 30 and $50 \%$ considering the texture as an important factor. Although the soils were sandy, runoff on the conservation plots was lower than the plots without mulch application. The analytical results in this experiment showed that the differences in textural fractions among soil classes were not sufficient to influence the runoff results. Brodie and Mishra (2009) obtained outcomes around $50 \%$ in runoff reduction with the residue incorporation: $16 \mathrm{~kg} \mathrm{~m}^{-2}$ for fresh material and $50 \mathrm{~kg} \mathrm{~m}^{-2}$ for aged green waste. Montenegro et al. (2013) showed a decrease of $45 \%$ after the application of $0.4 \mathrm{~kg} \mathrm{~m}^{-2}$ of rice straw. In the same experiment, they recorded a reduction of $22 \%$ with $0.2 \mathrm{~kg} \mathrm{~m}^{-2}$, and as conclusion, the said that increasing mulch cover density allowed a higher water retention. Another study conducted by Findeling et al. (2003) found that runoff coefficient was reduced by $50 \%$ on average due to the addition of $1.5 \mathrm{Mg} \mathrm{ha}^{-1}$ of corn residue. These authors concluded that a small amount of residue could dramatically cut down the runoff even in a bare unplanted soil.

\subsection{Infiltration rate $\left(\mathrm{K}_{1 \mathrm{~h}}\right)$}

The infiltration rate showed a great increase in B treatments compared to $\mathrm{S}$ and $\mathrm{C}$, and for this reason the treatment factor was statistically significant $(p<0.01)$. S and $\mathrm{C}$ registered similar outcomes (Fig. 2c and d), and B improved the infiltration rate by 60.7 and $67.2 \%$ ( $\mathrm{S}$ and $\mathrm{C}$ respectively). Thierfelder and Wall (2009) concluded that the final infiltration rate was generally higher in mulched treatments than 
Table 4. Statistical summary of results divided in soil classes.

\begin{tabular}{|c|c|c|c|c|c|c|}
\hline Statistical variables & Soil class & Runoff (mm) & Soil loss $\left(\mathrm{g} \mathrm{m}^{-2}\right)$ & Sediment concentration $\left(\mathrm{g} \mathrm{L}^{-1}\right)$ & Time to runoff (min) & Infiltration rate $\left(\mathrm{mm} \mathrm{h}^{-1}\right)$ \\
\hline Mean & I & 18.2 & 644.1 & 30.7 & 1.99 & 55.89 \\
\hline Median & & 19.7 & 371.7 & 23.5 & 1.79 & 43.96 \\
\hline SD & & 9.3 & 743.8 & 23.34 & 1.35 & 29.94 \\
\hline Var. & & 86.7 & 553300.9 & 544.90 & 1.82 & 896.66 \\
\hline Max. & & 28.1 (C WC) & 2068.2 (C WC) & 73.6 (C WC) & 4.0 (B WOC) & 115.0 (B WOC) \\
\hline Min. & & 0.5 (B WOC) & 29.1 (B WOC) & 11.8 (B WC) & 0.4 (C WOC) & 32.8 (C WC) \\
\hline Mean & II & 20.6 & 431.6 & 19.7 & 1.9 & 52.9 \\
\hline Median & & 21.4 & 227.8 & 11.7 & 2.1 & 49.1 \\
\hline SD & & 6.1 & 396.4 & 15.6 & 0.9 & 18.1 \\
\hline Var. & & 36.9 & 157100.2 & 241.9 & 0.9 & 325.9 \\
\hline Max. & & 27.7 (S WC) & 992.1 (C WC) & $40.2(\mathrm{C} \mathrm{WC})$ & 3.3 (B WOC) & 85.9 (B WOC) \\
\hline Min. & & 0.2 (B WOC) & 131.1 (B WOC) & 6.5 (S WOC) & $0.54(\mathrm{C} W C)$ & $35.0(\mathrm{~S}$ WC) \\
\hline Mean & III & 16.5 & 334.3 & 16.3 & 1.5 & 65.5 \\
\hline Median & & 17.4 & 139.6 & 8.5 & 1.4 & 61.7 \\
\hline SD & & 6.4 & 390.6 & 15.4 & 1.1 & 21.0 \\
\hline Var. & & 41.5 & 152544.5 & 236.2 & 1.2 & 441.8 \\
\hline Max. & & 24.9 (C WC) & 963.7 (C WC) & $38.6(\mathrm{C} \mathrm{WC})$ & 3.0 (B WOC) & 93.0 (B WOC) \\
\hline Min. & & 7.7 (B WOC) & 40.1 (S WOC) & 2.7 (S WOC) & 0.3 (C WC) & 37.6 (C WC) \\
\hline Mean & IV & 20.1 & 511.4 & 23.8 & 1.9 & 53.9 \\
\hline Median & & 19.1 & 234.5 & 10.1 & 2.1 & 52.4 \\
\hline SD & & 4.2 & 493.4 & 22.3 & 1.1 & 14.4 \\
\hline Var. & & 17.9 & 243429.1 & 497.3 & 1.3 & 205.9 \\
\hline Max. & & $26.0(\mathrm{C} \mathrm{WC})$ & 1155.8 (C WOC) & 59.9 (C WOC) & 3.2 (B WOC) & 75.6 (B WOC) \\
\hline Min. & & 14.9 (B WOC) & 143.5 (B WOC) & 9.4 (B WOC) & 0.54 (C WC) & 40.9 (C WC) \\
\hline
\end{tabular}

where $\mathrm{S}$ denotes superficial, B buried, $\mathrm{C}$ control, WOC without crust and WC with crust.

in control, and they registered similar outcomes in finedmedium-textured soils (57 to $87 \%$ ). In sandy soil, the improvement was only around $45-49 \%$. The influence of the soil condition on soil infiltration rate also showed statistically significant differences $(p<0.01)$. However, soil class factor did not show these statistical influences. The crust reduced the infiltration rate on average by $17.75 \mathrm{~mm} \mathrm{~h}^{-1}$ versus the non-crusted cases (Table 2). This outcome highlighted that crust on bare soil served as a barrier to the water infiltration because it reduced porous space and caused lower infiltration rates (Bielders et al., 1996). In Fig. 3a you can see that the buried incorporation improved the infiltration rate, although the crust was present in the top layer. Authors like Thierfelder and Wall (2009) and Thierfelder et al. (2013) indicated that the non-tillage/mulch combination (surface application) resulted in the development of biological activity and the presence of roots. These situations increased the preferential flow of water (animal galleries and root channels) and therefore the infiltration rate. In our study, the infiltration rate increased, but there was no vegetation and biological activity development in the simulation trays, so it did not generate preferential channels for water movement. The residue application improved soil quality as you can see in the previous section, and for this reason the unique way for water infiltration was the increase of the matrix flow.

Figure 3 shows a large initial lessening on infiltration rate in the first minutes of the rainfall. The reasons were (i) the dry conditions of the soil in the experiment and (ii) the strong character of the rainfall intensity from the beginning. Under these conditions the entrapped air in the pores produced a quick break action over aggregates and the infiltration rate lessened sharply (Le Bissonnais, 1990). The buried mulch application protected against this process because it was a thicker layer of soil. Figure 3, shows that the B-WOC was almost constant over time unlike the other treatments.

In any case after residue addition, crusted soils (average value of $\mathrm{B}-\mathrm{WC}$ and $\mathrm{S}-\mathrm{WC}$ ) reduced on average the infiltration rate $15.15 \mathrm{~mm} \mathrm{~h}^{-1}$ with respect to bare crusted soil (C$\mathrm{WC}$ ), whereas non-crusted treatments (average value of $\mathrm{B}$ WOC and S-WOC) decreased $17.84 \mathrm{~mm} \mathrm{~h}^{-1}$ with respect to C-WOC (Fig. 2c and d). Coffee husk addition did not avoid the crust effect over infiltration rate.

In reference to soil class factor, although soil III showed the highest infiltration rate, the factor was not statistically significant. Morgan (1995), Cerdà (1996), Franzluebbers (2002) and Adekalu et al. (2006) demonstrated that there was an increase in the infiltration rate with the amount of organic matter content. In our study the high cover of the soil (80$85 \%$ ) and the presence of residue to the depth of up to $5 \mathrm{~cm}$ facilitated the physico-chemical processes, which favored the organic matter improvement.

\subsection{Soil losses}

The results of soil loss $\left(\mathrm{g} \mathrm{m}^{-2}\right)$ and sediment concentration $\left(\mathrm{g} \mathrm{L}^{-1}\right)$ for the different factors (treatment, soil condition and soil class) are shown in this section. The loss patterns revealed a reduction in the amount of soil loss $\left(\mathrm{g} \mathrm{m}^{-2}\right)$ due to the coffee husk mulch (Table 2 and Fig. $4 a$ and $b$ ). The 

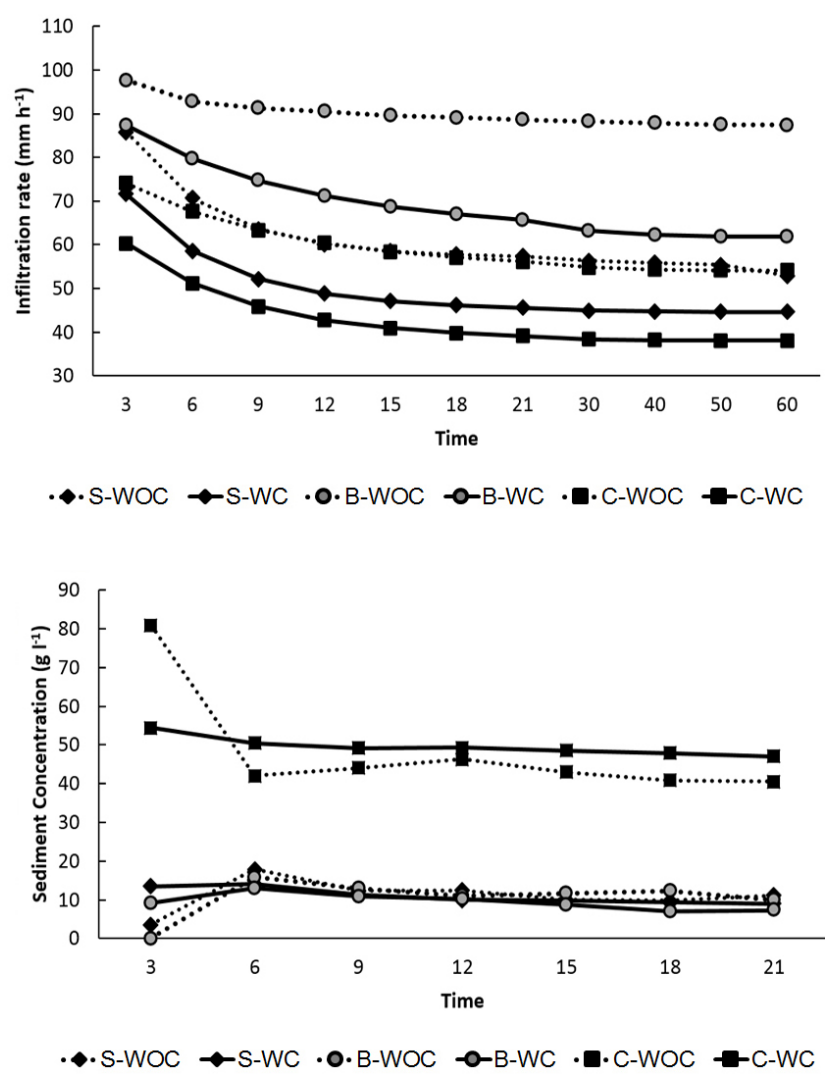

Figure 3. Temporal evolution of infiltration rate (by Horton) (a) and sediment concentration (b).

average value was lower in $\mathrm{B}$ treatments $\left(121.92 \mathrm{~g} \mathrm{~m}^{-2}\right)$ than in $\mathrm{S}\left(235.04 \mathrm{~g} \mathrm{~m}^{-2}\right)$ and $\mathrm{C}\left(1084.07 \mathrm{~g} \mathrm{~m}^{-2}\right)$, and they showed statistically significant differences among them. Coffee husk incorporation reduced soil losses by 88.7 and $78.3 \%$ respectively.

With the same trend, sediment concentration was reduced at least by $75.7 \%$ with the residue application. From Table 2, it can be seen that $\mathrm{B}$ and $\mathrm{S}$ treatments did not record significant differences between them (11.47 and $10.63 \mathrm{~g} \mathrm{~L}^{-1}$ respectively), although both values were lower than $\mathrm{C}$ treatments $\left(46.19 \mathrm{~g} \mathrm{~L}^{-1}\right)$ (Fig. $4 \mathrm{c}$ and $\mathrm{d}$ ). In that case, $\mathrm{C}$ treatments showed statistically significant differences with $\mathrm{S}$ and B.

Neither soil losses nor sediment concentration showed statistically significant differences on soil condition. However, soil loss was reduced by $31.8 \%$ between WOC treatments and WC (Table 2). In the case of sediment concentration, the reduction was lower $(2.45 \%)$.

This situation could seem contradictory, because the reduction in soil losses was really important $\left(181.68 \mathrm{~g} \mathrm{~m}^{-2}\right)$. The cause was that the treatment factor had a similar effect over the amount of lost sediment. Thus, trays with and without crust recorded similar soil loss values. S and B showed low values compared to $\mathrm{C}$ treatments, which registered the highest values in both erosive variables.

In sediment concentration, the smallest difference between WC and WOC $\left(0.66 \mathrm{~g} \mathrm{~L}^{-1}\right)$ was determined by analogous decreases in both runoff volumes and the amount of eroded sediment. The runoff variation was $29.7 \%$, whereas the soil loss variation was $31.8 \%$, so the sediment concentration showed only a modification of $2.45 \%$. The outcomes of sediment concentration were similar (Table 2), so this fact revealed that the erosive response in WOC and WC was the same. However, this response was displaced over time due to the difference in the onset of runoff. The advance of the onset to runoff was $35.5 \%$ higher in non-crusted trays with respect to crusted situations.

In Fig. 3b, you can show the large differences in sediment concentration due to treatments. Residue incorporation in both cases (B and S) resulted in cleaner water flows than $\mathrm{C}$ treatments. The values were constant from 12 to $15 \mathrm{~min}$ after the onset of rainfall to the end of the simulation. This fact indicated that the material mobilized by overland flow came from the aggregate breakdown, which was caused by the direct impact of the drops. The values were smaller than bare soil because the residue coverage (80-85\%) absorbed kinetic energy of rainfall (Bielders et al., 1996).

In relation to these results, the maximum values of sediment concentration were registered after $6 \mathrm{~min}$ of rainfall start. At the first measurement $(3 \mathrm{~min}$ ), some trays did not record runoff. Figure $3 \mathrm{~b}$ confirms that crust presence did not modify the sediment concentration in the treatments where the coffee husk was added. For this reason, the behavior of S-WOC, S-WC, B-WOC and B-WC was approximately the same since minute 6 . This situation was completely distinct in $\mathrm{C}$ treatments. Initially in such cases, the value of the concentration was very high in the WOC trays; then it declined sharply and finally it was stabilized around $40 \mathrm{gL}^{-1}$. The evolution of the sediment concentration followed a classic pattern of depletion: at first the flow of water dragged all loose particles that were on the soil surface, and, once eliminated, it was the impact of raindrops which provided new material (Kinell, 2005). When the soil was bare (C), the disaggregation was greater and runoff took more sediments than in $\mathrm{S}$ and B. In C-WC cases, the pattern of depletion was not followed because the soil particles were retained by the crust, and therefore its initial value was smaller than C-WOC. Once the time of this effect was overtaken, the sediment concentration was constant around $47 \mathrm{~g} \mathrm{~L}^{-1}$.

Soil losses showed a similar behavior as sediment concentrations (Fig. 4). In that sense, all soils showed higher losses in control treatments than in buried and superficial treatments. However, soil class was not significant over soil loss or sediment concentration.

Other researchers have found similar outcomes with other mulches. Donjadee and Chinnarasri (2012) showed in field experiments with a portable rainfall simulator (55 and $140 \mathrm{~mm} \mathrm{~h}^{-1}$ ) that grass mulch cover reduced soil loss by 

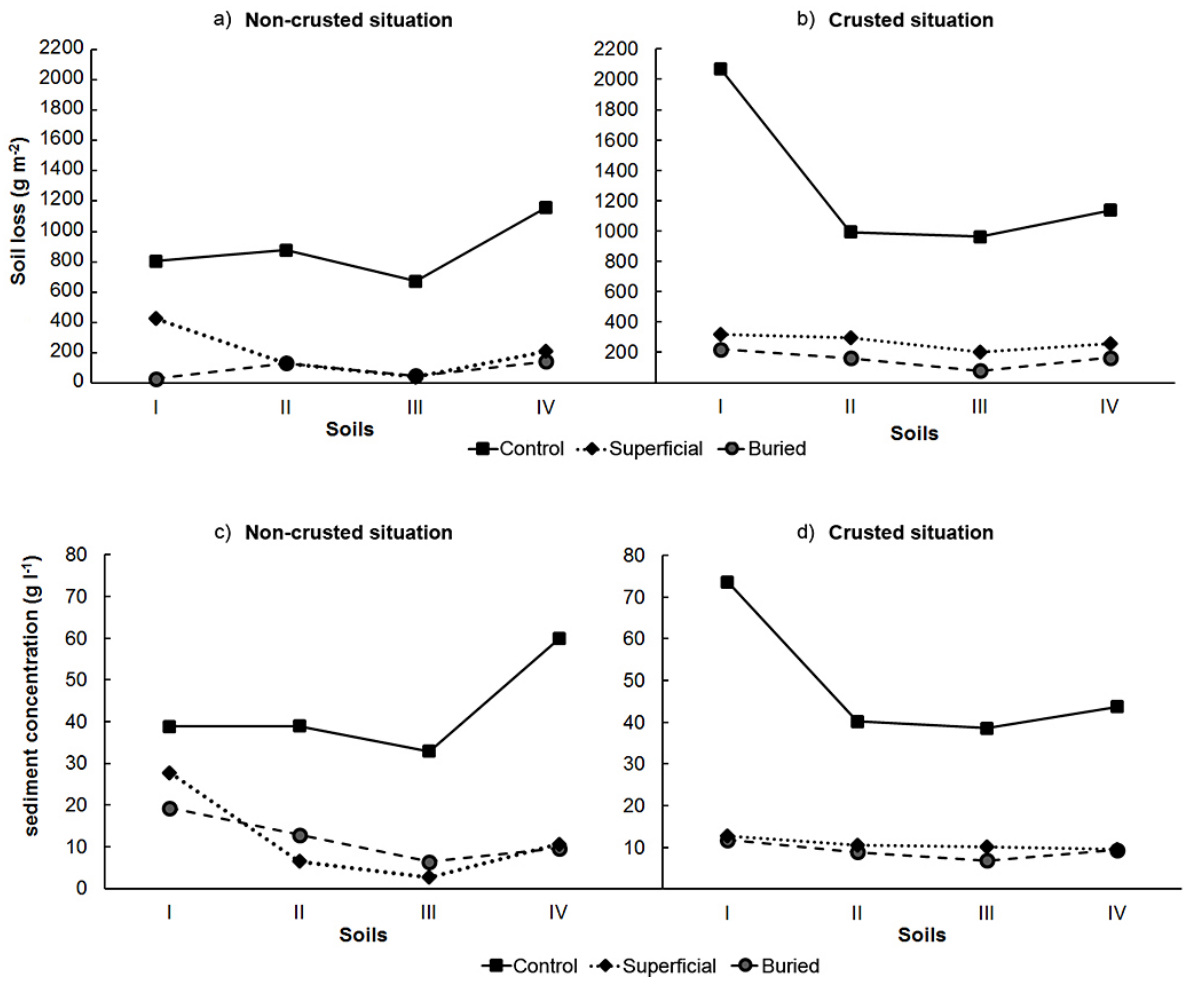

Figure 4. Behavior of erosive variables in function of the studied factors: soil loss (a) without crust, (b) with crust, and sediment concentration (c) without crust, (d) with crust.

$33.7-82 \%$. The use of other soil covers like wheat straw or grass seeds (Groen and Woods, 2008), a combination of straw and pine needles or pine needles (Grismer and Hogan, 2005), forest residues (Prats et al., 2012) or compost (Bakr et al., 2012) showed a reduction between 74 and $87 \%$ in soil erosion compared to the bare soils. The differences in the outcomes could be due to the variability of experiment conditions and the mulch. Poesen and Lavee (1991) showed that, for a given cover percentage, the decreases of soil losses were related to the size of the individual elements. The highest soil loss reduction values were registered with the smallest particles of mulch. The coffee husk had small diameter particles $(0.5-1.5 \mathrm{~cm})$ and the showed values of soil loss reduction were in the same range that the maximum values registered in the literature review, so the coffee husk size could have an advantage, which should be taken into account for future studies.

Although Grosbellet et al. (2011) revealed that the improvement of soil physical properties increased over time with the incorporation of organic matter and it could affect runoff, Leys et al. (2007) showed in their experimental cases that crusting and total soil cover were more important in controlling runoff/soil losses than the organic matter content or the texture.

In reference to the measurements of sediment concentration, research has registered high variability in results. Bakr et al. (2012) showed a decrease around $72 \%$ after the wood chip application. Jin et al. (2008) registered values higher than $92 \%$ and Grismer and Hogan (2004) obtained concentration values between 0.2 and $15 \mathrm{~g} \mathrm{~L}^{-1}$. These outcomes depended on the coverage (bare, needle mulches pines or pines, bare or wheat straw, and compost/mulch thickness respectively) and the slope class (48-72\%). Gholami et al (2012) registered a reduction in sediment concentration between 32 and $60 \%$ (depending the rainfall intensity) after the straw mulch application. In relation to the crust/non-crusted situations, Le Bissonnais et al. (2005) found that the mulch presence in crusted tilled fields decreases the sediment concentration by $20-65 \%$. Its efficiency depended on the precipitation intensity and the soil moisture status.

\section{Conclusions}

The outcomes of this study show clearly that coffee husk could be used as mulch to reduce soil erosion problems.

1. The coffee husk can be used as an erosion protector because it increases the infiltration rate, decreases the runoff amount, and the time to runoff is delayed. In the same way, soil loss and sediment concentration decrease after coffee husk application. 
2. The residue shows a higher efficiency when it is buried because it stimulates an improvement in soil quality parameters and it obtains the best outcomes in all the studied variables. When the residue is spread on the surface, the soil quality is improved at a lower degree, and the results do not show a good improvement in runoff depth and infiltration rate. In these cases the soil response is similar to the control treatments.

3. Coffee husk cannot cushion the effect of crust. In crusted soils the action of burying or spreading the coffee husk does not maintain the same response of soil against the rainfall.

4. The differences among the studied soils (salinity, organic matter content, etc.) do not show statistically significant differences. However, coffee husk improves the soil quality, and therefore it has been a good improver for that type of soils.

As a general conclusion, on the one hand, coffee husk reduces soil losses, sediment concentration and runoff depth; on the other hand, it increases the time to runoff and infiltration rates, so it can be used as mulch for soil protection against erosion. With low mulch application rates $\left(1.6 \mathrm{~kg} \mathrm{~m}^{-2}\right)$ and under loamy textured soils, the outcomes have been satisfactory. For these reasons, future detailed studies will be necessary for determining the effectiveness of this by-product in field conditions.

Edited by: A. Cerdá

\section{References}

Abdelkadir, A. and Yimer, F.: Soil water property variations in three adjacent land use types in the Rift Valley area of Ethiopia, J. Arid Environ., 75, 1067-1071, 2011.

Adekalu, K. O., Okunade, D. A., and Osunbitan, J. A.: Compaction and mulching effects on soil loss and runoff from two southwestern Nigeria agriculture soils, Geoderma, 137, 226-230, 2006.

Bakr, N., Weindorf, D. C., Zhu, Y., Arceneaux, A. E., and Selim, H. M.: Evaluation of compost/mulch as highway embankment erosion control in Louisiana at the plot-scale, J. Hydrol., 468469, 257-267, 2012.

Bekalo, S. A. and Reinhart, H.-W.: Fibers of coffee husk and hulls for the production of particleboard, Mater. Struct. 43, 10491060, 2010.

Bielders, C. L., Baveye, P., Wilding, L. P., Drees, L. R., and Valentin, C.: Tillage-induced spatial distribution of surface crusts on a sandy Paleustult from Togo, Soil Sci. Soc. Am. J., 60, 843855, 1996.

Bodí, M. B., Muñoz-Santa, I., Armero, C., Doerr, S. H., MataixSolera, J., and Cerdà, A.: Spatial and temporal variations of water repellency and probability of its occurrence in calcareous Mediterranean rangeland soils affected by fire, Catena, 108, 1425, 2013.
Brodie, I. M. and Misra, R. K.: Evaluation of greenwaste mulch to control runoff quality from landfill sites during frequent storms, Water Air Soil Pollut., 201, 75-85, 2009.

Calvo-Cases, A., Boix-Fayos, C., and Imeson, A. C.: Runoff generation, sediment movement and soil water behaviour on calcareous (limestone) slopes of some Mediterranean environments in southeast Spain, Geomorphology, 50, 269-291, 2003.

Cerdà, A.: Seasonal variability of infiltration rates under contrasting slope conditions in southeast Spain, Geoderma, 69, 217-232, 1996.

Cerdà, A.: The influence of aspect and vegetation on seasonal changes in erosion under rainfall simulation on a clay soil in Spain, Can. J. Soil Sci., 78, 321-330, 1998.

Cerdà, A.: Effects of rock fragment cover on soil infiltration, interrill runoff and erosion, Eur. J. Soil Sci., 52, 59-68, 2001.

Cerdà, A. and Doerr, S. H.: The effect of ash and needle cover on surface runoff and erosion in the immediate post-fire period, Catena, 74, 256-263, 2008.

Choi, I. S., Wi, S. G., Kim, S.-B., and Bae, H.-J.: Conversion of coffee residue waste into bioethanol with using popping pretreatment, Bioresour. Technol., 125, 132-137, 2012.

Donjadee, S. and Chinnarasri, C.: Effects of rainfall intensity and slope gradient on the application of vetiver grass mulch in soil and water conservation, Int. J. Sed. Res., 27, 168-177, 2012.

El Kateb, H., Zhang, H., Zhang, P., and Mosland, R.: Soil erosion and surface runoff on different vegetation covers and slope gradients: a field experiment in sourthern Shaanxi Province, China, Catena, 105, 1-10, 2013.

Ellison, W. D.: Studies of raindrop erosion. Agr. Eng., 25, 131-136 and 181-182, 1944

Fernández, C., Vega, J. A., Jiménez, E., Vieira, D. C. S, Merino, A., Ferreiro, A., and Fonturbel, T.: Seeding and mulching + seeding effects on post-fire runoff, soil erosion and species diversity in Galicia (NW Spain), Land Degrad. Dev., 23, 150-156, 2012.

Findeling, A., Ruy, S., and Scopel, E.: Modeling the effects of a 9-partial residue mulch on runoff using a physically based approach, J. Hydrol., 275, 49-66, 2003.

Franzluebbers, A. J.: Water infiltration and structure related to organic matter and its stratification with depth, Soil Till. Res., 66, 197-205, 2002.

Gangwar, K. S., Singh, K. K., Sharma, S. K., and Tomar, O. K.: Alternative tillage and crop residue management in wheat after rice in sandy loam soils of Indo-Gangetic plains, Soil Till. Res., 88, 242-252, 2006.

García-Orenes, F., Roldán, A., Mataix-Solera, J., Cerdà, A., Campoy, M., Arcenegui, V., and Caravaca, F.: Soil structural stability and erosion rates influenced by agricultural management practices in a semi-arid Mediterranean agro-ecosystem, Soil Use Manage., 28, 571-579, 2012.

Gholami, L., Hamnidreza, S., and Homaee, M.: Straw Mulching effect on splash erosion, runoff, and sediment yield from eroded plots, Soil Sci.Soc.Am.J., 77, 268-278. 2012.

Grismer, M. E. and Hogan, M. P.: Simulated rainfall evaluation of revegetation/mulch erosion control in the lake Tahoe basin-1: Method assessment, Land degrade. Dev., 15, 573-588, 2004.

Grismer, M.E., and Hogan, M.P.: Simulated rainfall evaluation of revegetation/mulch erosion control in the lake Tahoe basin-3: Soil treatment effects, Land degrade. Dev., 16, 489-501, 2005. 
Groen, A. H. and Woods, S. W.: Effectiveness of aerial seeding and straw mulch for reducing post-wildfire erosion, north-western Montana, USA. Int. J. Wildl. Fire 17, 559-571, 2008.

Grosbellet, C., Vidal-Beaudet, L., Caubel, V., and Charpentier, S.: Improvement of soil structure formation by degradation of coarse organic matter, Geoderma, 162, 27-38, 2011.

Hockbridge E.: Healthy soil: healthy people, healthy planet, Soil Health, 7, 9-11, 2012.

Horton, R. E.: An approach towards a physical interpretation of infiltration capacity. Soil Sci. Soc. Am. Pro., 5, 399-417, 1940.

Hsu, S. M., Masce, P. E., Ni, C. F., and Hung, P. H.: Assessment of three infiltration formulas based on model fitting on Richards Equation, J. Hydrol. Eng., 7, 373-379, 2002.

Huang, J., Wu, P., and Zhao, X.: Effects of rainfall intensity, underlying surface and slope gradient on soil in?ltration under simulated rainfall experiments, Catena, 104, 93-102, 2012.

Ibáñez, S.: Estudio de la erosión hídrica en suelos desarrollados sobre margas: métodos de estima en bancales abandonados. (Doctoral Tesis). Universidad Politécnica de Valencia, Departamento de Producción Vegetal, 396 pp., 2001.

Jiménez, M. A., Fernández-Ondoño, E., Ripoll, M. A., CastroRodriguez, J., Huntsinger, L., and Navarro, F. B.: Stones and organic mulches improve the Quercus Ilex L. Afforestation success under Mediterranean climatic conditions, Land Degrad. Dev., doi:10.1002/ldr.2250, 2013.

Jin, K., Cornelis, W. M., Gabriels, D., Schiettecatte, W., De Neve, S., Lu, J., Buysse, T., Wu, H., Cai D., Jin, J., and Harmann, R.: Soil management effects on runoff and soil loss from field rainfall simulation, Catena, 75, 191-199, 2008.

Kasongo, R. K., Verdoodt, A., Kanyankagotem P., Baert, G., and Van Ranst, E.: Coffee waste as an alternative fertilizer with soil improving properties for sandy soils in humid tropical environments, Soil Use Manage., 27, 94-102, 2011.

Kinell, P. I. A.: Raindrop-impact-induced erosion processes and prediction: a review, Hydrol. Process. 19, 2815-2844, 2005.

Kukal, S. S. and Sarjkar, M.: Splash erosion and infiltration in relation to mulching and polyvinyl alcohol application in semi-arid tropics, Arch. Agron. Soil. Sci., 56, 697-705, 2010.

Laws, J. O.: Recent studies in raindrops and erosion. Agr. Eng., 21, 431-433, 1940

Lee, J.-W., Park, C.-M., and Rhee, H.: Revegetation of decomposed granite roadcuts in Korea: Developing Digger, evaluating cost effectiveness, and determining dimension of drilling holes, revegetation species, and mulching treatment, Land Degrad. Dev., 24, 591-604, 2013.

Le Bissonnais, Y.: Experimental study and modelling of surface crusting processes. . In: Soil erosion - experiments and models, edited by: Bryan R. B., Catena Suppl. 17. Catena Verlag, CAremlingen-Destedt, Germany, 13-28, 1990.

Le Bissonnais, Y., and Singer, M. J.: Crusting, runoff, and erosion response to soil water content and successive rainfalls, Soil Sci. Soc. Am. J., 56, 1898-1903, 1992.

Le Bissonnais, Y., Cerdana, C., Lecomtea, V., Benkhadraa, H., Souchèreb, V., and Martin, P.: Variability of soil surface characteristics influencing runoff and interrill erosion, Catena, 62, 111124, 2005.

Leys, A., Govers, G., Gillijns, K., and Poesen, J.: Conservation tillage on loamy soils: explaining the variability in interrill runoff and erosion reduction, Eur. J. Soil Sci., 558, 1425-1436, 2007.
Leys, A., Govers, G., Gillijns, K., Berkmoes, E., and Takken, I.: Scale effects on runoff and erosion losses from arable land under conservation and conventional tillage: the role of residue cover, Eur. J. Hydrol., 390, 143-154, 2010.

Ma, I. J. and Li, X.-Y.: Water accumulation in soil by gravel and sand mulches: Influence of textural composition and thickness of mulch layers, J. Arid Environ., 75, 432-437, 2011.

Mashingaidze, N., Madakadze, C., Twomlow, S., Nyamangara, J., and Hove, L.: Crop yield and weed growth under conservation agriculture in semi-arid Zimbabwe, Soil Till. Res., 124, 102-110, 2012.

Montenegro, A. A., Abrantes, J. R. C. B., de Lima, J. L. M. P., Singh, V. P., and Santos, T. E. M.: Impact of mulching on soil and water dynamics under intermittent simulated rainfall, Catena, 109, 139-149, 2013.

Montgomery, D. R.: Soil and Civilization: Time for a Greener Revolution, Food Ethics, 7, 4-6, 2012.

Morgan, R. P. C.: Soil erosion and conservation. Second edition, Longman, ISBN0582244927, 2nd edition, 198 pp., 1995.

Murthy, P. S. and Naidu, M. M.: Sustainable management of coffee industry by-products and value addition - A review, Resour. Conserv. Recy., 66, 45-58, 2012.

Nearing, M. A., and Bradford, J. M.: Single waterdrop splash detachment and mechanical properties of soils. Soil. Sci. Soc. Am. J., 49, 547-552, 1985.

Pandey, C., Soccol, C. R., Nigam, P., Brand, B., Mohan, R., and Roussos, S.: Biotecnological potential of coffee pulp and coffee husk for bioprocesses, Biochem. Eng. J., 6, 153-162, 2000.

Prata, E. R. B. A. P., and Oliveira, L. S.: Fresh coffee husks as potential sources of anthocyanins, LWT-Food Sci. Technol., 40, 15551560, 2007.

Prats, S. A., MacDonald, L. H., Monteiro, M., Ferreira, A. J. D., Coelho, C. O. A., and Keizer, J. J.: Effectiveness of forest residue mulching in reducing post-fire runoff and erosion in a pine and eucalypt plantation in north-central Portugal, Geoderma 191, 115-124, 2012.

Poesen, J. W. A., and Lavee, H.: Effects of size and incorporation of synthetic mulch on runoff and sediment yield from interrils in a laboratory study with simulated rainfall, Soil Till. Res., 21, 209-223, 1991.

Saenger, M., Hartge, E.-U., Werthe, J., Ogada, T., and Siagi, Z.: Combustion of coffee husk, Renew. Ener. 23, 103-121, 2001.

Santos, J. C. F. I., Souza, I. F., Mendes, A. N. G., Morais, A. R., Conceição, H. E. O., and Marinho, J. T. S.: Allelophatic effect of coffee and rice husks arranged in soil layers on the germination and initial growth of Amaranthus viridis, Planta Daninha, 19, 197-207, 2001

Singh, B., Chanasyk, D. S., McGill, W. B., and Nyborg, M. P. K.: Residue and tillage management effects on soil properties of a typic cryoboroll under continuous barley, Soil Till. Res., 72, 117133, 1994.

Soil Survey Staff: Kellogg Soil Survey Laboratory Methods Manual, Soil Survey Investigations Report No. 42, Version 5.0, edited by: Burt, R. and Soil Survey Staff, US Department of Agriculture, Natural Resources Conservation Service, 2014.

Stavi, I., Lal, R., Jones, S., and Reeder, R. C.: Implications of cover crops for soil quality and geodiversity in a humid-temperate region in midwestern USA), Land Degrad. Dev., 23, 322- 330, 2012. 
Telis, P. A.: Estimation of infiltration rates of saturated soils at selected sites in the Caloosahatchee river basin, Southwestern Florida US Geological Survey, Open-File Report 01-65, 2001.

Thierfelder, C. and Wall, P. C.: Effects of conservation agriculture techniques on infiltration and soil water content in Zambia and Zimbabwe. Soil Till. Res., 105, 217-227, 2009.

Thierfelder, C., Mwila, M., and Rusinamhodzi, L.; Conservation agriculture in eastern and southern provinces of Zambia: Longterm effects on soil quality and maize productivity. Soil Till. Res., 126, 246-258, 2013.
Vandervaere, J. P., Vauclin, M., Haverkamp, R., Peugeot, C., Thony, J. L., and Gilfedder, M.: Prediction of crust-induced surface runoff with disc infiltrometer data, Soil Sci., 163, 9-21, 1998.

Zhao, G., Mu, X., Wen, Z., Wang, F., Gao, P.: Soil erosion, conservation, and Eco-environment changes in the Loess Plateau of China, Land Degrad. Dev., 24, 499-510, 2013.

Ziadat, F. M. and Taimeh, A. Y.: Effect of rainfall intensity, slope and land use and antecedent soil moisture on soil erosion in an arid environment, Land Degrad. Dev., 24, 582-590, 2013. 